\title{
Sequence of application and assessment of the means of physical rehabilitation of surgical patient after arthroscopic-controlled restoration of the anterior cruciate ligament
}

\author{
Beziazychna O.V. ${ }^{1}$, Litovchenko V.O. ${ }^{2}$, Pustovoit B.A. ${ }^{1}$, Litovchenko A.V. ${ }^{1}$ \\ ${ }^{1}$ Kharkiv State Academy of Physical Education \\ ${ }^{2}$ Kharkiv National Medical University
}

DOI: https://doi.org/10.34142/HSR.2020.06.01.01

\begin{abstract}
Aim of the study: to improve the results of rehabilitation treatment of surgical patient after damage to the anterior cruciate ligament of the knee joint.

Material and methods: General scientific, pedagogical observations, rehabilitation examination, medical and pedagogical testing, pedagogical experiment, visual analogue pain scale (VAS), Tegner-Lysholm scales, International Knee Documentation Committee (IKDC - 2000), methods mathematical statistics. The study involved men who were divided into 2 groups: the main (25) and control (23). The age of the examined varied from 25 to 44 years, on average in the main group $28.18 \pm 0.51$ years, and in the control $-27,15 \pm 0,59$.

Results: The results of rehabilitation treatment of surgical patient after damage to the anterior cruciate ligament of the knee joint by introducing an original program of physical rehabilitation at the preoperative and postoperative stage are presented. The place and role of electromyostimulation of the muscles of the anterior and posterior thigh groups in the process of physical rehabilitation are indicated.

Conclusions: In the course of the study, the feasibility of using physical rehabilitation means for the priority restoration of the tone, strength, and muscle mass of the posterior group of the lower limb was proved in comparison with the traditional program of physical rehabilitation.

Key words: physical rehabilitation programs; electromyostimulation; posterior thigh muscle group

\section{Анотація}

Без'язична О.В., Литовченко В.О., Пустовойт Б.А., Літовченко А.В. Послідовність застосування і оцінка засобів фізичної реабілітації постраждалих після артроскопічно-контрольованого відновлення передньої хрестоподібної зв'язки.

Мета роботи: покращити результати відновного лікування постраждалих після пошкодження передньої хрестоподібної зв'язки колінного суглоба.

Матеріал і методи. Загальнонаукові, педагогічні спостереження, реабілітаційне обстеження, лікарсько-педагогічне тестування, педагогічний експеримент, візуальна аналогова шкала болю (ВАШ), шкали Tegner-Lysholm, International Knee Documentation Committee (IKDC - 2000), методи математичної статистики. В дослідженні брали участь чоловіки, які були розподілені на 2 групи:

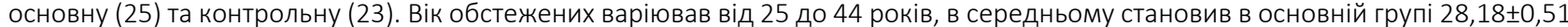
року, а в контрольній - 27,15 $\pm 0,59$.

Результати. Представлені результати відновного лікування постраждалих після пошкодження передньої хрестоподібної зв' язки колінного суглоба шляхом впровадження оригінальної програми фізичної реабілітації на доопераційному та післяопераційному етапі. Вказано місце та роль електроміостимуляції м'язів передньої і задньої груп стегна в процесі фізичної реабілітації.

Висновки. В ході дослідження доведена доцільність використання засобів фізичної реабілітації для пріоритетного відновлення тонусу, сили, маси м'язів задньої групи нижньої кінцівки в порівнянні з традиційною програмою фізичної реабілітації. Ключові слова: програми фізичної реабілітації; електроміостимуляція; задня група м'язів стегна
\end{abstract}

\section{Аннотация}

Безъязычная О.В., Литовченко В.А., Пустовойт Б.А., Литовченко А.В. Последовательность применения и оценка средств физической реабилитации пострадавших после артроскопически-контролированного восстановления передней крестообразной связки.

Цель работы: улучшить результаты восстановительного лечения пострадавших после повреждения передней крестообразной связки коленного сустава.

Материал и методы. Общенаучные, педагогические наблюдения, реабилитационное обследование, врачебно-педагогическое тестирование, педагогический эксперимент, визуальная аналоговая шкала боли (ВАШ), шкалы Tegner-Lysholm, International Knee Documentation Committee (IKDC - 2000), методы математической статистики. В исследовании принимали участие мужчины, которые были разделены на 2 группы: основную (25) и контрольную (23). Возраст обследованных варьировал от 25 до 44 лет, в среднем в основной группе 28,18 \pm 0,51 года, а в контрольной - 27,15 $\pm 0,59$.

Результаты. Представлены результаты восстановительного лечения пострадавших после повреждения передней крестообразной связки коленного сустава путем внедрения оригинальной программы физической реабилитации на дооперационном и послеоперационном этапе. Указано место и роль электромиостимуляции мышц передней и задней групп бедра в процессе физической реабилитации.

Выводы. В ходе исследования доказана целесообразность использования средств физической реабилитации для приоритетного восстановления тонуса, силы, массы мышц задней группы нижней конечности по сравнению с традиционной программой физической реабилитации.

Ключевые слова. программы физической реабилитации; электромиостимуляция; задняя группа мышц бедра 


\section{Introduction}

Knee injury is one of the most common injuries due to the high load on this segment and its anatomical features associated with jumps and sharp turns that occur during sports and dancing $[1,2]$. Damage to the knee joints and their complications in athletes is one of the reasons for premature interruption of sports career [3]. The most dangerous in terms of damage to the anterior cruciate ligament are skiing, contact and playing sports with "torn" acceleration and sharp braking, as well as ballet, ballroom and dance, all types of combat that combine the mechanism of injury - rotation. under weight loading $[4,5]$. In addition, given the accessibility of various sports, including extreme sports, damage to the anterior cruciate ligament is now common among the population that is not in the so-called risk zone [6, $7,8]$. Experts note that the athlete's intention to return to sports after trauma to the anterior cruciate ligament is the main indication for surgery $[9,10,11]$. According to various authors, from 55\% [12, 13] to 91\% [4] of athletes return to the big sport after surgery to reconstruct the anterior cruciate ligament. Safe return to sport after traumatic injury is a major indicator of the success of treatment, and this is due to the need to return the athlete in the shortest possible time, the ability not only to perform specific motor functions in the same volume as before the injury, and to endure tremendous physical activity, but also to achieve high sports results $[4,5,14,15]$.

With the full rupture of the anterior cruciate ligament, the anterior displacement of the tibia remains uncompensated, and the peculiarities of muscular compensation for the stability of the knee joint with such lesions are completely unclear.

Hypothesis. Muscle tension of the back thigh has a secondary effect - flexion in the knee joint and, as a result, the backward force vector. Hypothetically, the "agonist" of the anterior cruciate ligament is the muscle of the back of the thigh with the knee bent at the lower extremity. The development of these exercises contributes to the stabilization of the knee joint and improve intermuscle coordination $[16,17,18]$. Therefore, in our opinion, the physical rehabilitation of athletes with such impairment should be primarily aimed at the recovery of the muscles of the hindlimb of the lower extremity, despite all the previous studies where the priority in the complex of physical rehabilitation has been the restoration of the anterior thigh muscles.

The aim of the study: to improve the results of rehabilitation treatment of surgical patient after damage to the anterior cruciate ligament of the knee joint.

\section{Material and methods}

\section{Participants}

The study involved patients over 25-30 years old (men) with isolated damage to the anterior cruciate ligament with a body mass index of less than 30 . The control group consisted of 23 patients and the main group was 25 patients. The mean age of the victims in the control group was $27.15 \pm 0.59$ and in the main group was $28.18 \pm 0.51$.

\section{Procedure}

Performed a subjective evaluation of pain syndrome on the visual-analogue visual analog scale - VAS. The clinical and functional outcomes of treatment of patients with damage to the anterior cruciate ligament in all clinical groups were performed using the Tegner-Lysholm method. According to the Tegner-Lysholm scale, 8 criteria were considered, where at a value less than 65 points the result was considered unsatisfactory, values within $65-83$ points indicated a satisfactory result, 84 - 90 points were considered good and more than 90 were used. the IKDC - 2000 Knee Scale (International Knee Documentation Committee) is a form of subjective evaluation of the knee joint function at longer periods of the rehabilitation process, namely 38 weeks, 45 weeks, and 18 months [19].

\section{Experimental technique}

The physical rehabilitation program consisted of phases and periods identical for both groups. The preoperative period of physical rehabilitation in such patients lasted for two weeks and consisted of two phases: phase 0-1 (day 1-7), phase 2 (day 7-14).

After arthroscopically controlled surgery, an early postoperative period of physical rehabilitation of up to 1 month was initiated, which also consisted of two phases: phase 3 (1-7 days after surgery), phase 4 (7-28 days after reconstruction).

The late postoperative period of physical rehabilitation was performed in terms of one month to 20 weeks, including after arthroscopically controlled intervention, the latter also divided into two phases: phase 5 was up to 10 weeks, phase 6 ranged from 10th to 21 st week.

The functional period ranged from one month to 25 weeks after reconstruction and was one phase - phase 7 . These four stages constituted the basic program of physical rehabilitation. The 
26-week period from the time of the injury, which included the pre-operative period - two weeks is key and it is likely that the results of the physical and physical rehabilitation of the victims with damage to the anterior cruciate ligament of the knee are likely. However, in our opinion, further curation of the rehabilitologist is necessary in order not to negate the surgeon's efforts and the activities of the entire basic physical rehabilitation program.

The recovery period or training was about 3 months and contained 8 phases from week 25 to week 39 . This is the period of final morphological reconstruction of the transplant and its revascularization processes with adequate physical activity.

The period of professional, sports rehabilitation also contained one - 9 phase from the 40th to the 46th week. It is for this period that the damage to the operatively restored anterior cruciate ligament is characterized by inadequate physical exertion (Table 1). It is during this period that the patient often loses contact with the rehabilitation physician and the subsequent physical rehabilitation program is not fully supervised by a specialist.

Periods of clinical and functional studies in patients with damage to the anterior cruciate ligament of the knee joint in the process of rehabilitation

\begin{tabular}{|c|c|c|c|c|c|c|}
\hline \multirow[b]{2}{*}{$\begin{array}{l}\text { System of assessment of } \\
\text { physical rehabilitation means }\end{array}$} & \multicolumn{6}{|c|}{$\begin{array}{l}\text { Periods of physical rehabilitation, number of examined } \\
\text { ill, } n\end{array}$} \\
\hline & 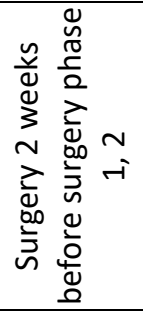 & 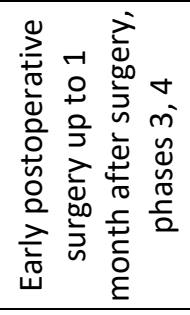 & 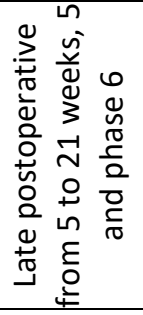 & 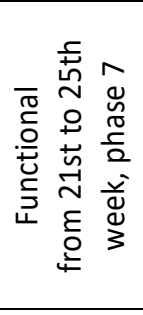 & 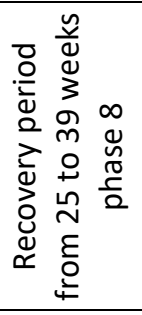 & 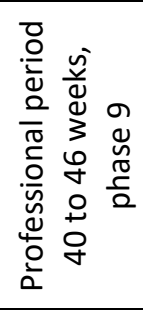 \\
\hline $\begin{array}{l}\text { Assessment of subjective pain } \\
\text { for you }\end{array}$ & 48 & 48 & 48 & 48 & 48 & 48 \\
\hline IKDC scale & 48 & 48 & 48 & 48 & 48 & 48 \\
\hline The Tegner-Lysholm scale & 48 & 48 & 48 & 48 & 48 & 48 \\
\hline
\end{tabular}

The program of physical rehabilitation in the patients of the control and the main groups consisted of therapeutic gymnastics, massage, physiotherapy procedures, which had their tasks and differences in each period of recovery treatment.

A comprehensive program of physical rehabilitation according to the traditional, established scheme in patients of the control group and the program developed and proposed for patients of the main group were in accordance with the general principles of rehabilitation after arthroscopic knee joint surgery.

In patients of the control group, electromyostimulation was applied to quadriceps femoris quadriceps femoris in the mode of 10 seconds parcel, 10 seconds pause in phase 2 of the preoperative period, phase 4 of the early postoperative period, phase 6 of the late postoperative period and phase 9 of the professional period that is consistent with current views on the principles of physical rehabilitation in such victims. In patients in the main clinical group, electromyostimulation was applied to three muscles of the posterior group of the lower extremity: the semi-tendon muscle - $\mathrm{m}$. semitedinosus, biceps - $\mathrm{m}$. biceps femoris, membranous muscle - $m$. semimembranosus and anterior muscles - only four head muscles of the thigh - quadriceps femoris in the mode of 10 seconds parcel, 10 seconds pause in the 2nd phase of the preoperative period, in the 4th phase of the early postoperative period, in the 6th phase of the late postoperative period and in the 9th phase of the professional period.

In the patients of the main group, the physical rehabilitation program is aimed at priority restoration of tone, strength, muscle mass of the back group of the lower extremity. Thigh biceps stretching exercises begin as early as phase 4 of the early postoperative period.

Control medical-pedagogical testing of all patients was first performed at the beginning of treatment in the pre-operative period at the preclinical stage and at the time of surgery. The following patient tests were performed at the 
specified times: 1 month after the fourth phase of physical rehabilitation, 20 weeks after the 6th phase, 24 weeks after the 7th phase of physical rehabilitation, 38 weeks after the 8 th phase, 45 weeks after the 9th phase.

\section{Statistical analysis}

The data were statistically processed, the mean $(\bar{x})$ and its standard error (S) were calculated. Assessment of quality indicators of treatment results was performed using the Pearson Chi-square $\left(\chi^{2}\right)$ criterion. The level of statistical significance was considered significant at a value less than $0.05(\mathrm{p}$ $<0.05)$. Prior to the experiment, the groups did not differ significantly.

\section{Results}

On the Tegner-Lysholm scale, the baseline knee function score of the victims of the main group immediately after trauma was $42.9 \pm 1.8$ points, which did not differ ( $p>0.05)$ from the similar indicator of the control group - $(42.8 \pm 1.7)$ points, and indicates the urgent need for physical rehabilitation measures, followed by surgical treatment. The average VAS score in patients was close ( $p>0.05): 6.9 \pm 0.8$ points in the main group and $6.8 \pm 0.6$ points in the control group, which required analgesia and also physical rehabilitation. Arthrologic status according to the index of motor function of the knee, according to the IKDC-2000 scale in patients indicated significant damage to the knee joint: $46,66 \%$ in the main group and $45,09 \%$ of the control, which statistically ( $>>0,05)$ was close.

At the end of the preoperative period, the absence of atrophic manifestations of the muscles of the lower extremities, preserved muscular strength in the healthy extremity, complete recovery of the volume of movements in the knee joint testify to the realization of the goals and measures of physical rehabilitation of the preoperative period. Impaired anatomic-functional joints of the joint elements also lead to stagnation of pain in both clinical groups - 7.0 \pm 0.6 points in the control group, $6.8 \pm 0.2$ points in the main, which is not statistically significant ( $p>$ 0.05 ). The assessment of arthrologic status on the Tegner-Lysholm scale at the time of surgery in the main group was $43.1 \pm 1.6$ points and in the control $(42.9 \pm 1.8)$ points, which was also statistically close ( $>$ > 0.05). The index of motor function of the knee joint, according to the IKDC-2000 scale in patients in the control group of $47.09 \%$ and the main $46.84 \%$ was also not statistically significant ( $p>0.05$ ), and also indicates the need for further medical and physical rehabilitation.
1 month after reconstruction of the anterior cruciate ligament, pain in the control group patients tended to abate and was VAS $4.8 \pm 0.2$, which was statistically significant $(\mathrm{p}<0.05)$ greater than in patients of the main group $-2.8 \pm 0.2$ points, because in phase 4 of the early postoperative period, electromyostimulation of all groups of the muscles of the lower extremity was performed, which probably has significantly greater ontological properties. Score arthrologic status in the control group according to the Tegner-Lysholm scale was $52.9 \pm$ 2.1 points, and was statistically significant $(\mathrm{p}<0.05)$ lower than in the patients of the main group $-75.9 \pm$ 2.4 points, and this result should be interpreted as satisfactory. The index of motor function of the knee, according to the IKDC-2000 scale after the 4th phase of physical rehabilitation in the patients of the control group was $49.29 \%$, and statistically significant ( $p$ $<0.05$ ) was lower than in the patients of the main group $69.49 \%$, but had not yet reached the norm and was, accordingly, statistically significant $(\mathrm{p}<0.05)$ smaller than it. However, in the main group, the index of motor function of the knee joint tends to normalize and also indicates the need for further physical rehabilitation and the transition to the late postoperative period of the physical rehabilitation program.

Again, in phase 6, electromyostimulation of the anterior and posterior thigh muscles was performed in the victims of the main group, unlike patients in the control group, where electromyostimulation was applied only to the muscles of the anterior group. On the TegnerLysholm scale, the arthroscopic status score was 77.2 \pm 2.6 points, indicating a satisfactory result. In patients in the control group with a score of $62.8 \pm$ 2.1 points, the result was considered unsatisfactory and was statistically significant $(\mathrm{p}<0.05)$ worse than in the main group. Score on the VAS scale in both groups was statistically close ( $p>0.05$ ), and was 2.4 \pm 0.2 points in the main group and $2.8 \pm 0.2$ points in the control group, indicating adequacy physical rehabilitation programs. The index of motor function of the knee, according to the scale IKDC-2000 after the 6th phase of physical rehabilitation in patients of the main group has already approached $(77,49 \pm$ $1,95) \%$, but still statistically significant $(\mathrm{p}<0.05)$ differed from the norm, in the control group also tended to improve $(65.78 \pm 1.68) \%$, but noted its slow recovery, although at the time of review the difference was statistically close ( $p>0.05$ ).

6 months after surgery, the index of motor function of the knee, according to the scale IKDC2000 after the 7th phase of physical rehabilitation in patients in the main group was $87.49 \pm 1.95 \%$ and control group $-87.11 \%$ at $100 \%$, and is no longer 
significantly different from the norm, and provides the opportunity to transition to the recovery period of the physical rehabilitation program. The average scores according to the Tegner-Lysholm scale, where the grade point was $78.4 \pm 1.2$ points in the main group $71.2 \pm 1.2$ points and the control, indicate a completely satisfactory result, as well as on the VAS scale the score became $1,6 \pm 0.2$ points and $1.8 \pm 0.2$ points respectively, which is the criterion for the transition to the next phase.
At this stage, it was considered appropriate to evaluate the preliminary results of the baseline physical rehabilitation program in the control group and the main group patients (Table 2), using the Tegner-Lysholm main assessment scale. It should be noted that in the control group the overwhelming majority of patients had satisfactory results, the indicators of only three patients were within the good, but unsatisfactory results and differences did not occur at the end of this period.

Table 2

The results of treatment of patients on the Tegner-Lysholm scale after 26 weeks (phase 7) (absolute value, $\%$ )

\begin{tabular}{cccc}
\hline \multirow{2}{*}{ Group } & \multicolumn{2}{c}{ Results of treatment } & \multirow{2}{*}{ Total } \\
\cline { 2 - 3 } & Good & Satisfactory & $25(100,0 \%)$ \\
\hline Basic & $10(40,0 \%)$ & $15(60,0 \%)$ & $23(100,0 \%)$ \\
\hline Control & $3(13,0 \%)$ & $20(87,0 \%)$ & \\
\hline Total & $35(72,9 \%)$ & $13(27,1 \%)$ & \\
\hline \multirow{2}{*}{ Significance of Differences } & & $\chi^{2}=4,408$ \\
& & $\mathrm{p}=0,036$ & \\
\hline
\end{tabular}

Therefore, by assessing the benchmarks of the basic part of the program of physical rehabilitation in patients of sportsmen and sports lovers with damage to the anterior cruciate ligament, it should be noted that more adequately selected means and methods of physical rehabilitation have led to more good results and more dynamic and better clinical and qualitative indicators at the stages of testing in patients of the main group (10 (40\%)), compared with the control, where there were only 3 $(13.0 \%)$ patients. The overall distribution of treatment outcomes showed a statistically significant difference $(\mathrm{p}=0.036)$ between the groups. With a view to returning to previous sports activities, it is advisable to continue the program of physical rehabilitation and the immediate transition to a recovery or training period.

At the end of Phase 8, the Tegner-Lysholm score in the main group was $(79.2 \pm 1.2)$ points, which was rated as close to a good result, the control score was $(69.8 \pm 1.2)$, which was generally regarded as a satisfactory stable result, but it should be noted that no improvement in results during the recovery period occurred. On a scale, YOUR indicator gained $(1.2 \pm 0.2)$ points in the primary and $(1.7 \pm 0.3)$ points in the control groups. The index of motor function of the knee, according to the scale IKDC-2000 after the 8th phase of physical rehabilitation in patients of the main group is almost close to $(89,49 \pm 1,25) \%$, which is not statistically different ( $p>0,05)$ from the norm , as well as in the control group $(86.12 \pm 1.78) \%$.

At the end of the professional period, the index of motor function of the knee joint, according to the IKDC-2000 scale after the 9th phase of physical rehabilitation in patients of the main group amounted to $(91,51 \pm 1,47) \%$, in the control group, respectively $(87,11 \pm 1,68) \%$, which completely corresponds to normalization, and is not statistically different from the norm, and between groups ( $p>$ $0.05)$. On the VAS scale, the main group scored (1.1 $\pm 0.1)$ points, which is statistically more significant $(\mathrm{p}<0.05)$ than in the control group $(1.7 \pm 0.3)$. Score on the Tegner-Lysholm scale in the main group was $(81.8 \pm 1.4)$, indicating that the result was close to good, and in the control $(71.1 \pm 1.3)$, indicating that it was completely satisfactory. the result, however, should be noted that there was no improvement in results during the functional, restorative and professional periods in this group. The treatment outcomes of patients in both groups were evaluated according to the Tegner-Lysholm scale (Table 3).

Thus, after the 9th phase of physical rehabilitation, the number of patients with good treatment outcome increased in the main group - 15 $(60.0 \%)$, in contrast to the control group, where one patient became worse and the number of good results decreased to $2(8.7 \%)$ of patients.

According to the analysis, the distribution of treatment outcomes in the groups was statistically significantly different $(\mathrm{p}=0.001)$.

In the long-term period, 18 months after surgery (Table 4), patients in the main group experienced a gradual increase in good results up to $68.0 \%$ (in 17 patients) and a corresponding decrease in satisfactory results $(8(32.0 \%)$, whereas in the control of $3(13.0 \%)$ patients the result of treatment worsened, the restoration of the condition to good increased by 1 patient and amounted to 3 (13.0\%).

The dynamics of change in the results of treatment of patients during the observation and in the distant period is shown in Fig. 1. 
The results of treatment of patients on the Tegner-Lysholm scale after 45 weeks ( 9 phases of physical rehabilitation)

\begin{tabular}{cccc}
\hline \multirow{2}{*}{ Group } & \multicolumn{3}{c}{ Results of treatment } \\
\cline { 2 - 4 } Basic & Good & Satisfactory & Total \\
\hline Control & $15(60,0 \%)$ & $10(40,0 \%)$ & $25(100 \%)$ \\
\hline Total & $2(8,7 \%)$ & $21(91,3 \%)$ & $23(100 \%)$ \\
\hline \multirow{2}{*}{ Significance of Differences } & $17(35,4 \%)$ & $31(64,6 \%)$ \\
& & $\chi^{2}=13,785$ \\
$\mathrm{p}=0,001$ & \\
\hline
\end{tabular}

The results of treatment of patients on the Tegner-Lysholm scale after 18 months

\begin{tabular}{ccccc}
\hline \multirow{2}{*}{ Group } & \multicolumn{3}{c}{ Results of treatment } & \multirow{2}{*}{ Total } \\
\cline { 2 - 5 } Gasic & Good & Satisfactory & Non-Satisfactory & $25(100 \%)$ \\
\hline Control & $3(68,0 \%)$ & $8(32,0 \%)$ & - & $23(100 \%)$ \\
\hline Total & $20(41,7 \%)$ & $17(73,9 \%)$ & $3(13,0 \%)$ & \\
\hline Significance of Differences & & \multicolumn{3}{c}{$\begin{array}{c}\chi^{2}=15,984 \\
\mathrm{p}=0,001\end{array}$} \\
\hline
\end{tabular}

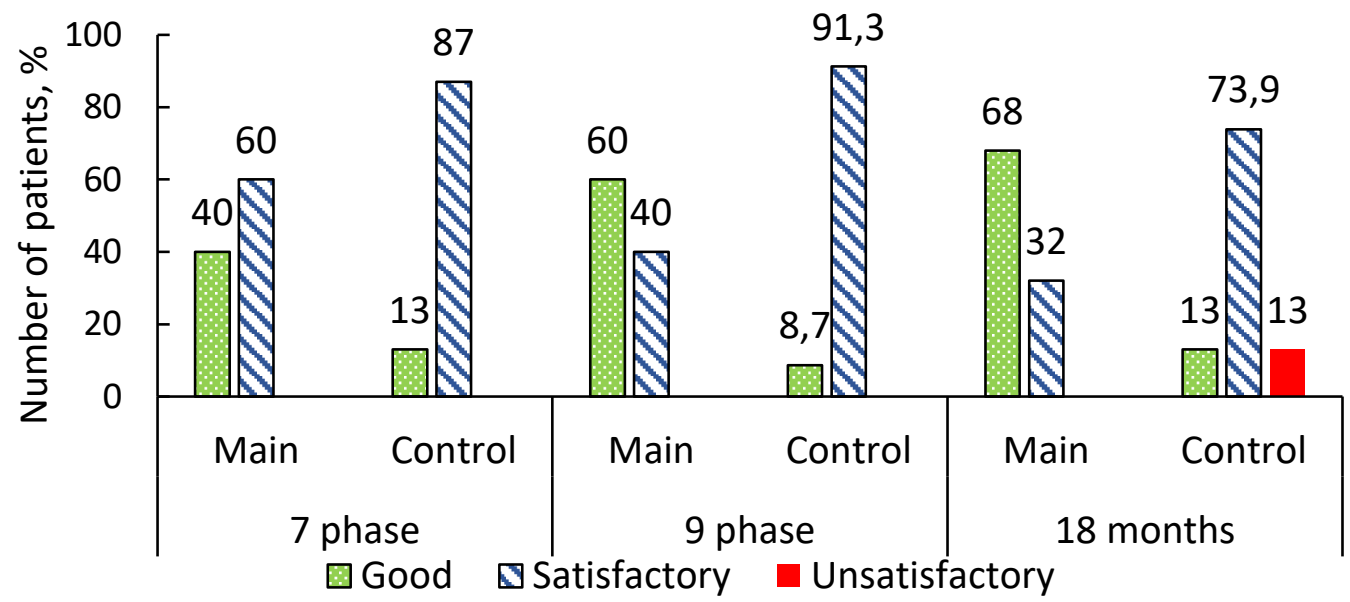

Fig. 1. Diagram of dynamics of recovery of function of a knee joint on the Tegner-Lysholm scale during the observation

Thus, the proposed program of physical rehabilitation of patients with damage to the anterior cruciate ligament is more effective, and the means and methods of physical rehabilitation are justified.

\section{Discussion}

Today there is a considerable amount of work devoted to the rehabilitation of patients after arthroscopic reconstruction of the anterior cruciate ligament, taking into account the use of various ligament transplants, fixation methods, periods of use of the means of restoration of the motor function of the damaged limb $[6,8,11]$. However, many issues regarding the recovery of patients with damage to the anterior cruciate ligament are debatable, including determining the optimal timing of surgery, and identifying the most effective means of rehabilitation to minimize postoperative complications $[15,18]$.

Roy et al. [15] developed a criterion-oriented rehabilitation program for patients after reconstruction of the anterior cruciate ligament, which includes successive periods with the introduction of specific tasks for each of them and the corresponding criteria for the transition to the next period. The authors introduced the concept of criteria for each of the rehabilitation periods. Only the 
fulfillment of all criteria of a certain period is the reason for the transition to the next. This approach ensures the speed and safety of returning the patient to the usual level of activity and makes this long process controlled

Porchinskaya and others [20] developed a rehabilitation complex for early recovery of knee joint mobility using metered exercise. At the same time, the authors took into account the functional condition of the athlete, his level of training. In the developed complex, patients have been walking slowly without orthopedic crutches since 4 days after surgery, and have also learned to walk on stairs. From the third week after surgery, knee stretching exercises were added.

Davydenko and Gagara [21] present the results of studies of the evaluation of the impact on the body of patients with damage to the knee joint specially selected complex of physical rehabilitation. The rehabilitation program included therapeutic physical training, massage, hydro-kinesitherapy, magneto-laser therapy, phonophoresis with the drug "Biol", electrical stimulation of the muscles of the lower extremity, training in a passive trainer. The use of the complex allowed to obtain reliable results of improvement of indicators of functional status of patients of the experimental group. The authors envisage further research in the direction of studying the problems of physical rehabilitation of patients with damage to the anterior cruciate ligament of the knee.

The author presents the author's program of complex rehabilitation of sportsmen of game sports after reconstruction of the anterior cruciate ligament [22]. A characteristic feature of the program is a comprehensive approach to solving the problem of rehabilitation of athletes with the use of modern tools and methods that affect both the restoration of stability and mobility of the injured joint, muscle tone and inter-muscle coordination of the injured limb, as well as the restoration of proprioception and special motor skills. The program is designed for six periods. This made it possible to distribute the means and methods used in the program, taking into account the anatomo-morphological features of the processes of reconstruction after anterior cruciate ligament, local status of the knee joint, physiological rates of recovery of impaired motor function of the lower extremity, as well as general and sports.

In addition to the author's complexes of physical rehabilitation after arthroscopic repair of the damaged anterior cruciate ligament, we have found in literature sources works devoted to specific methods of rehabilitation, which, in our opinion, may further develop into the development of a complex of rehabilitation measures in the pathologic pathology of the knee.

There are a number of works in the literature $[23,24]$ on the effects of open and closed kinematic chains on the strength of the anterior cruciate ligament during postoperative recovery. Both closed and open kinematic systems can be safely applied after plastic anterior cruciate ligaments, opening additional possibilities for the patient to expand the arsenal of exercises and prevent uniformity of training.

The literature data [24] state the tendency of using modern technologies in rehabilitation. Yes, mechanical rehabilitation with the use of mechanotherapy on the REV-9000 complex allows to recover movements in the knee after arthroscopy of the anterior cruciate ligament within 2-3 weeks, which is 2-3 times faster than with the use of physical training.

The widespread use of knee arthroscopy has stimulated the development of new methods and complexes of physical rehabilitation of postoperative recovery of athletes. Therefore, the issues of the impact of complex programs of physical rehabilitation of athletes with damage to the anterior cruciate ligament of the knee joint on the restoration of the function of the lower extremity remain poorly understood and need further development.

Stabilization of the knee is performed by the most significant ligaments: two lateral tibia and tibial collateral ligaments, and two internal - anterior and posterior cruciate ligaments. In addition, the stability of the joint is provided by active (dynamic) stabilizers, which include the musculoskeletal complex. Extension in the knee joint is performed by a four-headed hip muscle (straight muscle, wide medial muscle, wide lateral muscle, wide intermediate muscle). Bending at the knee joint is performed by three muscles, the initial part of which is located in the area of the gluteal hilum: twoheaded, semi-membranous and semi-tendon muscle of the thigh.

During rehabilitation, it is important to take into account the possibility of relapse, mainly anterior-medial instability, due to the weakness of the stabilizing elements of the joint - the medial collateral ligament, the quadriceps femur. On this basis, it is clear why a great deal of attention in the research of both domestic and foreign authors on this problem is devoted to the restoration of the quadriceps muscle of the thigh [15]. Hypothetically, the "agonist" of the anterior cruciate ligament is the muscle of the back of the thigh with the knee bent at the lower extremity. Muscle tension of the back thigh has a secondary effect - flexion in the knee joint and, as a result, the backward force vector.

A holistic view of the knee joint as a balanced system of support and movement, knowledge of anatomy and fundamentals of biomechanics is a solid foundation for the development of rehabilitation programs after arthroscopic surgery.

Physical rehabilitation programs should include, first of all, medical gymnastics, orthopedic treatment, and the use of electrical stimulation.

Much work has been devoted to the use of electromyostimulation of muscles as part of a physical rehabilitation program after arthroscopic 
reconstruction of the anterior cruciate ligament [18]. The use of electrical stimulation for hypotrophy of the muscles involved in stabilization of the knee joint (after arthroscopy of the anterior cruciate ligament), allows to compensate for the weakness of the muscles-extensors of the knee joint of the operated limb, and also has a direct effect on adaptation since patients often cannot arbitrarily contract muscle within days after surgery.

Therefore, the feasibility of justifying a physical rehabilitation program focused on restoring the tone, strength, and muscle mass of the back thigh is obvious.

\section{Conclusions}

1. Means of physical rehabilitation of patients with damage to the anterior cruciate ligament are aimed at the primary restoration of the muscles of the posterior group of the lower extremity reliably effective.

2. A physical rehabilitation program for athletes and sports enthusiasts with damage to the anterior cruciate ligament with regard to the phases and periods after arthroscopically-controlled reconstruction of the anterior cruciate ligament has better stabilized anatomic-functional anatomy.

3. The Tegner-Lysholm physical rehabilitation assessment system is the most objective.

\section{Acknowledgements}

The study was conducted according to priority thematic area 76.35. "Medical and biological substantiation of carrying out restorative means of physical rehabilitation to young people of different level of training". State registration number is $0116 \mathrm{U} 004081$.

\section{Conflict of interest}

Authors state that there is no conflict of interest.

\section{References}

1. Griffin L, Agel J, Jlbohm A, Arendt E, Dick R, Garrett W. Noncontact anterior cruciate ligament injuries: risk factors and prevention strategies. J Am akad Orthop Surg. 2000; 8: 141-50. (in English)

2. Bez'yazichna O. Vikoristannya masazhu ta fizioterapiyi pislya artroskopichnih operacij na kolinnomu suglobi. Slobozhanskij naukovo-sportivnij visnik. 2014; $3 \quad$ (41): $\quad$ S. 23-25. doi.org/10.15391/snsv.2014-3.004. (in Ukrainian)

3. Bogatov V, Bahteeva N, Mitrofanov V. Otdalennye rezultaty artroskopicheskih vmeshatelstv pri travmah kolennogo sustava u detej. Travmatologiya i ortopediya Rossii. 2010; 3: S. 55-60. (in Russian)

4. Haertdinov I, Fartdinov M. Opyt hirurgicheskogo lecheniya povrezhdenij perednej krestoobraznoj svyazki kolennogo sustava. Prakticheskaya medicina. 2015; 4: S. 189-190. (in Russian)

5. Ardern C, Webster K, Taylor N, Feller J. Return to sport following anterior cruciate ligament reconstruction surgery: a systematic review and metaanalysis of the state of play. Br J Sports Med. 2011; 45: R. 596-606. (in English)

6. Rusanov A. Suchasnij poglyad na problemu zastosuvannya zasobiv fizichnoyi reabilitaciyi pri artroskopichnih operativnih vtruchannyah u hvorih $\mathrm{z}$ ushkodzhennyam perednoyi hrestopodibnoyi zv'yazki. Sportivna medicina i fizichna reabilitaciya. 2017; 1: S. 97-103. (in Ukrainian)

7. Sanders T, Maradit Kremers H, Bryan A. Larson D, Dahm D, Levy B, Stuart M, Krych A. Incidence of Anterior Cruciate Ligament Tears and Reconstruction: A 21-Year Population-Based Study. Am J Sports Med.
2016 ; 44(6): 1502-7. doi.org/10.1177/0363546516629944. (in English)

8. Pezzullo D, Fadale R. Current controversies in rehabilitation afteranterior cruciate ligament reconstruction. Sports Med. Arthrosc. 2010; 18: P. 4347. (in English)

9. Tickaya E, Antipova I, Barabash L, Abdulkina N, Naumov A, Dostovalova O, Zamulina E. Kompleksnaya reabilitaciya sportsmenov $\mathrm{s}$ zabolevaniyami sustavov i periartikulyarnyh tkanej s ispolzovaniem lechebnyh fizicheskih faktorov. Medicina i obrazovanie Sibiri [Internet]. 2013 [citovano 2020 Lyut. 27]; 6. Dostupno na : http://ngmu.ru/cozo/mos/article/abauthors.php?id=11 98. (in Russian)

10. Logerstedt D, Arundale A, Lynch A, Snyder-Mackler L. A conceptual framework for a sports knee injury performance profile (SKIPP) and return to activity criteria (RTAC). Braz J Phys Ther. 2015; 19: R. 34059. (in English)

11. Ardern C, Taylor N, Feller J, Webster K. Fifty-five percent return to competitive sport following anterior cruciate ligament reconstruction surgery: an updated systematic review and meta-analysis including aspects of physical functioning and contextual factors. Br J Sports Med. 2014; 48: R. 1543-52. (in English)

12. Brukner P, Karim K. Clinical Sports Medicine. 4th ed. Collana: Medicina; 2012. 1296 r. (in English)

13. Makmaon P, Uyba V, editors. Sports trauma: diagnostics and treatment: translation from English. M: Practice, 2011. 366 r. (in English) 
14. Williamson E. Fear Avoidance Behavior Questionnaire. Austrailian Journal of Physiotherapy. 2006; 52: 149. (in English)

15. Kostrub A, redaktor. Reabilitaciya posle artroskopicheskih operacij u sportsmenov. Kiev; 2015. 436 s. (in Russian)

16. Bez’yazichna O, Litovchenko V, Pustovojt B. Programa fizichnoyi reabilitaciyi paciyentiv pislya artroskopichno kontrolovanoyi rekonstrukciyi perednoyihrestopodibnoyi zvyazki. Aktualni pitannya patologiyi suglobiv ta endoprotezuvannya: materiali IV vseukrayinskoyi naukovo-pratkichnoyi konferenciyi; 2019 Ver. 12-14; Zaporizhzhya: ZDMU, DU «Institut patologiyi hrebta ta suglobiv im. prof. M.I.Sitenka»; 2019,s. 9-10.

17. Nikanorov O. Zastosuvannya zasobiv fizichnoyi reabilitaciyi u sportsmeniv igrovih vidiv sportu pislya rekonstrukciyi perednoyi shreshenoyi zv'yazki (na prikladi doslidzhennya tonusu chotirigolovogo m'yaza stegna). Teoriya i metodika fiz. vihovannya i sportu. 2014; 1: S. 61-65. (in Ukrainian)

18. Samohin A. Zastosuvannya elektromiostimulyaciyi ta likuvalnoyi gimnastiki u hvorih $\mathrm{z}$ gipotrofiyeyu chotirigolovogo m'yaza stegna $\mathrm{v}$ rannomu pislyaoperacijnomu periodi pislya artroskopichnoyi rekonstrukciyi perednoyi hrestopodibnoyi zv'yazki. Molodizhnij naukovij visnik. 2017; 26: S. 84-87. (in Ukrainian)

19. Tegner E, Lysholm J. The Reliability, Validity, and Responsiveness of the Lysholm Score and Tegner Activity Scale for Anterior Cruciate Ligament Injuries of the Knee. The American Journal of Sports Medicine. 2009; 5(37) :890-7. (in English)

20. Porchinska K, Macejko I, Sheryemyetyeva Yu. Fizichna reabilitaciya sportsmeniv pislya travm kolinnih suglobiv. Pedagogika, psihologiya i medikobiologicheskie problemy fizicheskogo vospitaniya i sporta. 2009; 11: S. 83-86. (in Ukrainian)

21. Davidenko O, Gagara V. Fizichna reabilitaciya hvorih $\mathrm{z}$ poshkodzhennyami perednoyi hrestopodibnoyi zv'yazki kolinnogo suglobu $\mathrm{v}$ pislyaoperacijonomu periodi. Problemi fizichnogo vihovannya i sportu. 2011; 7: S. 19-21. (in Ukrainian)

22. Nikanorov O. Metodichni aspekti fizichnoyi reabilitaciyi sportsmeniv igrovih vidiv sportu $\mathrm{Z}$ ushkodzhennyam perednoyi hrestopodibnoyi zv'yazki kolinnogo sugloba. Molodizhnij naukovij visnik Shidnoyevropejskogo nacionalnogo universitetu imeni Lesi Ukrayinki. Fizichne vihovannya i sport. 2013; 11 : S. 56-61. (in Ukrainian)

23. Morrissey M., Perry M, King J. Is knee laxity change after ACL injury and surgery related to open kinetic chain knee extensor training load? Am. J. Phys. Med. Rehabil. 2009; 88: R. 369 375. (in English)

24. Kolomiec T. Effektivnost primeneniya kompyuternogo mehanicheskogo kompleksa REV9000 pri reabilitacii pacientov $\mathrm{s}$ travmoj perednej krestoobraznoj svyazki. Fizichne vihovannya, sport i kultura zdorov'ya u suchasnomu suspilstvi: zbirnik naukovih prac. - 2013; 1: S. 288-291. (in Russian)
Information about the authors

\section{Beziazychna O.V.}

orcid.org/0000-0001-9987-6405

obezyazychnaya@gmail.com

Kharkiv State Academy of Physical Education

Klochkivska st., 99. Kharkiv, 61058, Ukraine

Litovchenko V.O.

Lyt_v@ukr.net

Kharkiv National Medical University

Nauky Avenue, 4. Kharkiv, 61022, Ukraine

\section{Pustovoit B.A.}

orcid.org/0000-0001-7534-4404

pustovoit203@gmail.com

Kharkiv State Academy of Physical Education

Klochkivska st., 99. Kharkiv, 61058, Ukraine

\section{Litovchenko A.V.}

weunp@ukr.net

Kharkiv State Academy of Physical Education

Klochkivska st., 99. Kharkiv, 61058, Ukraine

\section{Інформація про авторів}

\section{Без'язична О.В.}

orcid.org/0000-0001-9987-6405

obezyazychnaya@gmail.com

Харківська державна академія фізичної культури вул. Клочківська, 99. Харків, 61058, Україна

\section{Литовченко В.О.}

\section{Lyt_v@ukr.net}

Харківський національний медичний університет пр. Науки, 4. Харків, 61022, Україна

Пустовойт Б.А.

orcid.org/0000-0001-7534-4404

pustovoit203@gmail.com

Харківська державна академія фізичної культури вул. Клочківська, 99. Харків, 61058, Україна

\section{Літовченко А.В.}

weunp@ukr.net

Харківська державна академія фізичної культури вул. Клочківська, 99. Харків, 61058, Україна 